\begin{tabular}{r|cr|c}
\hline 150 & $\begin{array}{c}\text { NEWS } \\
\text { Luhomír hLAVIENKa }\end{array}$ & $\begin{array}{r}\text { Research Trends and Sources on Industrial Work Force } \\
\text { in the Gzech Lands from } 1938 \text { to } 1948\end{array}$ \\
\hline
\end{tabular}

\title{
Research Trends and Sources on Industrial Work Force in the Czech Lands from 1938 to 1948
}

\author{
Praha, Czech Republic, \\ 3 - 4 December 2014
}

This workshop took place in the House of Trade Unions in Prague from 3 to 4 December 2014 and was organized by researchers coming from the Faculty of Public Policies of the Silesian University in Opava and from the Institute for Contemporary History, research institute of the Academy of Sciences of the Czech Republic. The workshop was divided in three sections. Two were held on 3 December and one on 4 December.

Labour force is considered as social group in the interest sphere of politicians as well as subject sui generis. The third importance of labour force is the role in political changes after 1945. This project is a combination of historical and sociological views.

The first day dealt with methodological problems of research in the sphere of industrial work force, furthermore the archival sources were discussed. A few of academic papers, whose content will be summarized in this report, were heard.

Jiři Kocián from the Institute for Contemporary History, research institute of the Academy of Sciences of the Czech Republic, presented his topic "The Position of Labourers in the Political Programs of the Czechoslovak National Socialist Party after 1945". He stated that trade unions of the national socialist party had a lot of members in the metal working industry before World War II.

After World War II the National Socialists were trying to include members of organizations which were a part of forbidden parties, e. g. national democrats and agrarians. In view of the fact that the party recruited the members from middle and lower social classes ideological disputes between social democrats and communists occurred. Despite this fact negotiations on merger of trade unions of national socialists and of social democrats were proceeded. Nevertheless, these activities were observed negatively by party members and in the end the merger was refused. The executive board was criticized because it was not interested in the situation of lower social classes. It contrasted with the political profile of above mentioned parties.

The second presentation named "State Policy of Employment and its Reflection in the Slovak Society 1945 - 1948" was given by Katarína Kožáková who arrived from Slovakia. Katarína Kožáková described structural changes connected with industrialization since 1930s. She pointed out that the number of people employed in industry rose in 1930s, nevertheless about $50 \%$ of population were peasants. Generally, Slovakia was lacking in skilled workers.

The following paper was prepared by Peter Heumos. He focused on strikes in the Czechlands from 1918 to 1968. The analyzed era includes four types of regimes - the Czechoslovak Republic, the Protectorate and then he divides the post-war time 1945 - 
1968 in two periods: 1945 - 1948 the people's democracy and the final period lasts from the communist coup d'état to the Prague Spring, therefore, it is quite complicated to find any long-lasting structures. In the period 1918 - 1938 strikes were spontaneous instruments how to reach a share on production and improve social position and welfare of labourers. The state stood apart and trade unions did not fulfill their functions. Peter Heumos also said that sending deputations consisting of striking labourers to the president Masaryk or other authorities was, compared to Germany, usual. The last German deputation visited the emperor in 1889.

During the Protectorate trade unions were necessary for mobilization of workers, strikes and refusals of work were found as a form of sabotage and the resistance against occupational powers. These activities were punished. Strikes had unpolitical nature and focused on social matters. Nevertheless, trade unions were supported. Their role was seen in mobilization of labourers.

400 strikes occurred in the era 1948 - 1968 and only a part of the workshop or of the company took part in it. Disputes were solved on the working place where a competent minister was invited. He discussed objections with workers. It happened quite often among miners. In that case, problems were debated directly in the coal mine. The Communist Party was trying to prevent from a mere attempt of a strike and since 1948 strikes were found as terrorist acts. In this period 100,000 workers were punished for resistance on the working place.

Alžběta Čornejová from the Trade Unions Archive of the Czech Moravian Confederation of Trade Unions (Všeodborový archív ČMKOS) opened the afternoon session. Her academic paper focused on in-house provisions for workers from 1938 to 1953. During the Protectorate the in-house provisions were a continuance of the canteens for poor people which were founded during the World War I. In-house provisions were introduced on the command of the Reich Protector Konrad Henlein and Kurt Daluege. It should have contributed to the improvement of the relationship of the inhabitants in the Protectorate to the German Reich. One principle was valid - those people who worked hard were given bigger rations, soups were important.

Principles of in-house provisions were in general accepted by communists. They also used in-house provisions for their ideology - they demonstrated their interest in welfare of labourers. Canteens for smaller factories were founded later and a new profession canteen cook was "born” as well.

Following presentation was held by Jiří Pokorný from the same institution as Alžběta Čornejová. Jiří Pokorný discussed the problem of the national competition after World War II from 1945 to 1948. It was interdepartmental activity among various ministries and industrial boards which was divided in three stages. The key task of the national competition was post-war reconstruction in Czechoslovakia. Antonín Zápotocký, who initially refused to be active, took part in the end. The most important initiators were industrial trade unions and trade unions in the agrarian sector. The expected contribution was a higher level of the industrial system and its reconstruction. The national competition was eroding gradually and in 1948 was replaced by a new institution namely by the Central Commission of Social Competition (Ústřední komise sociální soutěže).

The last speech of the first conference day was held by Martin Hubený from the National 
Archive in Prague who summarized archival sources concerning industrial work force in the era of the World War II which are deposited in the National Archive.

The official programme ended in the Trade Unions Archive of the Czech Moravian Confederation of Trade Unions which was founded on the occasion of the first congress of trade unions in 1946. This archive is a unique institution in Europe and its document collections represent extraordinary evidence of the life of Czech peoples in modern times, enlighten politics, social and cultural development. Therefore, this archive was categorized as archive of extraordinary importance. The function of this archive is collecting and publishing materials documenting the development of trade unions in the Czechlands.

The second day of the conference was devoted to possibilities of studying the industrial work force.

Firstly, Dušan Janák (sen.) presented questionnaires which were distributed among pupils in Brno in 1947. These questionnaires represent unique collection of information about the situation in post-war Brno. It must be stressed that Brno was the only town in the Central Europe where this study was undertaken after the end of World War II. The base for this part represents 1,000 questionnaires of pupils who attended different secondary schools. These questionnaires were chosen randomly.

The Second speaker was Tomáš Čížek from the Institute of Sociology of the Academy of Sciences of the Czech Republic. His paper concentrated on the sociological data archive. $\mathrm{He}$ mentioned that his team primarily works on contemporary researches and processes primal data. The research in Brno was rare, modern, demanding in the field of methodology as well as sociology.

Stanislav Kokoška from the Institute for Contemporary History, research institute of the Academy of Sciences of the Czech Republic, discussed statistical sources to the history of labourers in 1939 - 1945. Statistics had an important role in the Protectorate. It is evident because the State Statistical Office (Státní úrad statistický) came under German control very soon. Industrial production was very important for Germans. The aim of the State Statistical Office was gaining information from factories which had more than six employees. Questionnaires took into account general information about the factory, consumption, production, water and gas supplies. Later, they were trying to monitor strikes, wages and production costs according to ration card. The outputs were reports of the Office, price data or annual statistic almanac.

Lubomír Hlavienka summed up possibilities of using daily press in the research of the industrial work force in the period from 1945 to 1948. The second part of his speech was content analysis of articles which have been found during the research of his team consisting of Ph.D. students at the Silesian University. They researched in Práce, Věstník $\mathrm{ROH}$ and Dnešek which totally contrasts Práce and Věstník $\mathrm{ROH}$, because was published by the Czechoslovak National Socialist Party.

The last paper "Stav a možnosti výzkumu nucené práce v českém průmyslu v letech 19451948" was held by Dušan Janák (sen.). The problem of forced work is a specific phenomenon. Legal base of camps of forced work is included in the law No. 247/48 Collection of Laws. Czechoslovakia was criticized because of it by the International Labour Organization. Dušan Janák summarized who was isolated in working camps and divided four categories of forced work. There were several camps of forced labour in Czechoslovakia, e. g. in 
Plzeň and Kladno. The second extreme represents voluntary work when whole age groups worked for example in agriculture.

Lubomír HLAVIENKA

Faculty of Public Policies Silesian University in Opava

Czech Republic 